\title{
LiberTy, EQuality AND THE Right to MarRy UNDER THE FourTEENTH AMENDMENT
}

\author{
Ian Loveland* \\ Department of Law, City University, \\ London and Arden Chambers
}

\begin{abstract}
The legitimacy of recent judgments in the Supreme Court, lower federal courts and State courts which have extended the scope of the Due Process and/or Equal Protection clauses of the Fourteenth Amendment has been a fiercely contested controversy in legal and political circles in the USA. The controversy has been especially sharp in relation to the question of same sex marriage, and specifically whether it is within State competence to refuse to allow same sex couples to marry under State law. This paper explores that legitimation controversy through a multi-contextual analysis of the Supreme Court's starkly divided judgment in Obergefell $v$ Hodges (2015), in which a bare majority of the Court concluded that a State ban on same sex marriage was incompatible with the Due Process clause of the Fourteenth Amendment. This paper critiques both the majority and dissenting opinions, and suggests that while one might applaud the substantive conclusion the Court has reached, the reasoning offered by the majority suffers from several obvious weaknesses both in narrow doctrinal terms and from the broader perspective of safeguarding the Court from well-founded criticism that it is overstepping the bounds of its legitimate constitutional role.
\end{abstract}

\section{CONTENTS}

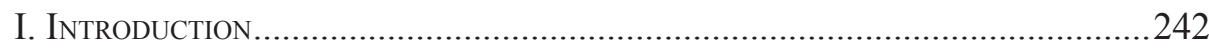

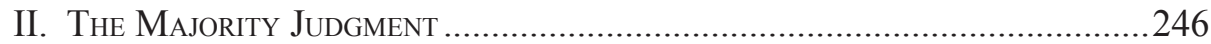

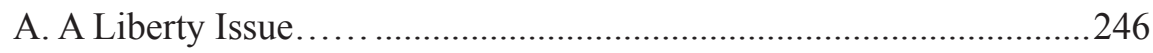

B. .....And/Or an Equal Protection Issue ..........................................252

C. On the Separation of Powers ........................................................253

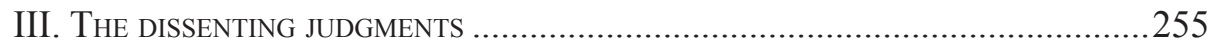

A. Chief Justice Roberts .........................................................256

B. Justice Scalia ......................................................................25

III. Conchusion.............................................................................. 260

* Department of Law, City University, London and Arden Chambers 


\section{INTRODUCTION}

One need not have been blessed with atypical powers of prediction to appreciate that the U.S. Supreme Court's decision in United States v. Windsor ${ }^{1}$ would promptly lead the Court to consider the much more significant issue of whether States could refuse to recognize same-sex marriages. ${ }^{2}$ That question had last been put squarely before the Court over forty years ago, in Baker v. Nelson, ${ }^{3}$ when it was summarily dismissed as raising no constitutional issue. In Windsor, a 5-4 majority had concluded that s.3 of the Federal Defense of Marriage Act 1996 (DOMA) was inconsistent with the Fifth Amendment. S.3 was a broad interpretation clause, which provided that any reference to 'marriage' in federal legislation should be construed as referring only to marriages between a man and a woman. The effect of s.3 was to deny any benefits accruing to married couples under such legislation to same sex spouses. DOMA had been a pre-emptive strike against the possibility that some States might permit same sex marriages, ${ }^{4}$ and seems to have been enacted to give legislative force to majoritarian bigotry against homosexuals. ${ }^{5}$ It is a measure of

United States v. Windsor, 133 S. Ct. 2675 (2013).

2 See for example Catherine Jean Archibald, Is Full Marriage Equality for Same-Sex Couples Next - The Immediate and Future Impact of the Supreme Court's Decision in the United States v. Windsor, 48 VAL. U. L. Rev. 695 (2014); William Baude, Interstate Recognition of Same-Sex Marriage After Windsor, 8 N.Y.U. J. L.\& LiBerTy 150 (2013); Daniel Fuerst, Means to an Inevitable End: How the United States v. Windsor and the Fall of the Defense of Marriage Act Will Accelerate Marriage Equality Among All the States, 8 Fed. CTs. L. Rev. 51 (2014).

3 Baker v. Nelson, 409 U.S. 810 (1972). The suit was a remarkably innovative endeavor, brought by two student activists a Mr. Baker and a Mr. McConnell; see Marcia Coyle, The First Case: Forty Years On, NAT'L L. J. (23 August 2010) http://www.thelegalintelligencer.com/id=1202470971127?slreturn=20170730090023.

Minnesota legalized same-sex marriage in 2013. There is an intriguing p.s. to the claimant's legal failure. See Erik Eckholm, The Same Sex Couple Who Got a Marriage Licence in 1971, N.Y. Times (May 15, 2015) http://www.nytimes.com/2015/05/17/us/thesame-sex-couple-who-got-a-marriage-license-in-1971.html?_r=0:

The couple, though, did not give up. With some sleight of hand involving a legal change to a gender-neutral name, they obtained a marriage license in another county, and in 1971, in white bell-bottom pantsuits and macramé headbands, they exchanged vows before a Methodist pastor and a dozen guests in a friend's apartment. Their three-tiered wedding cake was topped by two plastic grooms, which a friend supplied by splitting two bride-and-groom figurines. Ever since, they have maintained that theirs was the country's first lawful same-sex wedding. The state and federal governments have yet to grant recognition, but the pastor, Roger W. Lynn, 76, calls theirs "one of my more successful marriages. They are still happily married, and they love each other," Mr. Lynn said.

4 Massachusetts was the first to do so, albeit by judicial construction of the State constitution rather than legislation: see Goodridge v. Dep't. of Pub. Health, 798 N. E. 2d 941 (Mass. 2003). For contemporaneous analysis see Dwight G. Duncan, How Brown Is Goodridge - The Appropriation of a Legal Icon, 14 B.U. PuB. Int. L. J. 27 (2004).

5 See the discussion of the Congressional debates in Ian Loveland, A Right to Engage in Same Sex Marriage in the USA, Eur. Hum. RTs. L. Rev. 10 at 12-13; Butler, The Defense of Marriage Act: Congress's Use of Narrative in the Debate Over Same Sex Marriage, 73 N.Y.U. L. Rev. 841 (1997). 
how swiftly the cultural landscape in the United States. has shifted in respect of sexual orientation discrimination that by the time Windsor came before the Court in 2103 a dozen States had legalized same sex marriage.

The majority judgment in Windsor invalidated s.3 on the basis that it infringed an individual liberty interest arising under the Fifth Amendment. That liberty was not for a person to marry another person of the same sex. DOMA did not purport to 'ban' such marriages, and save in Washington D.C. or the territories, Congress would have no such power in any event. The liberty in issue was an entitlement not to be denigrated, belittled and stigmatized by legislation motivated by moral disapproval of a person's sexual orientation. The majority also accepted that the Due Process clause of the Fifth implicitly contained a proviso equivalent to the Equal Protection clause under the Fourteenth, ${ }^{6}$ and seemingly indicated - but did not expressly assert - that sexual orientation discrimination had now become a 'suspect category' for equal protection purposes such that it could only be justified by compelling public policy concerns (which did not and could not include simple moral disapproval).

Even as Windsor was decided, a cluster of challenges to the laws in several of the States which prohibited same-sex marriage had been making their respective ways through the State and/or federal court systems. Obergefell consolidated four of those cases, which respectively called into question the laws of Michigan, Kentucky, Ohio and Tennessee.

The Tennessee law was contained in an amendment to the State constitution passed in 2006:

The historical institution and legal contract solemnizing the relationship of one man and one woman shall be the only legally recognized marital contract in this state. Any policy or law or judicial interpretation, purporting to define marriage as anything other than the historical institution and legal contract between one man and one woman is contrary to the public policy of this state and shall be void and unenforceable in Tennessee....

Constitutional amendment in Tennessee requires that a measure twice be passed in both houses of the legislature in successive sessions (by a bare majority on the first occasion and by a two thirds majority in the second) and then approved by a referendum. ${ }^{7}$ Some $81 \%$ of voters in the referendum supported the amendment. It could hardly be said therefore that the measure was the result of a transient, bare majoritarian legislative whim. Quite what motives underlay the amendment at the referendum stage is essentially unknowable, given that the overwhelming majority of the 'lawmakers' have not expressed any recorded view to explain why they voted as they did. One might however surmise that many of the good people Tennessee subscribed to - at least in the secluded anonymity of the ballot box - the presumption so prevalent in the late twentieth century United States that homosexuality ought to be designated as a deviant and inferior form of sexual orientation. ${ }^{8}$

6 Following the Warren Court's lead in Bolling v. Sharpe, 357 U.S. 497 (1954) - which contemporaneously with Brown v. Board of Education, 347 U.S. 483(1954) - invalidated racial segregation in Washington D.C. schools.

7 Tenn. Const. Art. IX, $\$ 3$.

8 The extraordinary vitriol which motivated many anti-gay marriage campaigns in the early 2000s is chronicled in Sean Cahill, The Anti-Gay Marriage Movement, in THE 
The same conclusion presumably applied to Kentucky's 2004 constitutional amendment which affirmed the previously legislative basis of the cross-gender nature of marriage: ${ }^{9}$

Only a marriage between one man and one woman shall be valid or recognized as a marriage in Kentucky. A legal status identical or substantially similar to that of marriage for unmarried individuals shall not be valid or recognized.

The Kentucky constitution is not so deeply entrenched as that of Tennessee. Amendment requires the support of three fifths of the members of each of the two legislative houses, and then approval by a bare majority in a referendum. ${ }^{10}$ Some $74 \%$ of Kentucky voters supported the proposal to prohibit same-sex marriage. ${ }^{11}$

The Michigan State legislature had prohibited same-sex marriages in 1995. The 'people' of the State then amended the State constitution in 2004:

To secure and preserve the benefits of marriage for our society and for future generations of children, the union of one man and one woman in marriage shall be the only agreement recognized as a marriage or similar union for any purpose.

The terms of Michigan's constitution are not deeply entrenched. Article XII of the State constitution ${ }^{12}$ provides for amendment of the constitution by majority support in a referendum approving either a proposal supported by two thirds of the members of the State legislature or a proposal supported in a petition by $10 \%$ of the electorate. The 2004 amendment was a petition initiative, which was supported at the referendum stage by a vote of $59 \%$ to $41 \%$. $^{13}$

On the same day, ${ }^{14}$ voters in Ohio approved a similar amendment to their State's constitution by a $62 \%$ - $38 \%$ majority: ${ }^{15}$

Politics of Same Sex Marriage 155 (Craig A Rimmerman \& Clyde Wilcox, eds. 2007). Much of the impetus came from evangelical protestant sects, although one might note that many avowedly religious Americans were vocal supporters of same sex marriage; see id. and David C. Campbell \& Carin Robinson, Religious Coalitions for and Against Gay Marriage: The Culture War Rages On, in Rimmerman \& Wilcox (eds.) id. at 131.

$9 \quad$ See Ellen D.B. Riggle \& Sharon S. Rotosky, The Consequences of Marriage Policy for Same-Sex Couples'Wellbeing, in Rimmerman \& Wilcox (eds.), supra note 8, at 75-78.

10 Ky. Rev. Stat. AnN §256; available at http://www.lrc.ky.gov/lrcpubs/ib59.pdf.

11 For a snapshot of the motives of 'Yes' voters see inter, alia, http://usatoday30.usatoday. com/news/politicselections/vote2004/2004-11-02-ky-initiative-gay-marriage_x.htm;

$12 \mathrm{http}: / /$ www.legislature.mi.gov/\%28S\%28ezcspdnkw5ft3loqteva $2 \mathrm{gzt} \% 29 \% 29 / \mathrm{docu}-$ $\mathrm{ments} / \mathrm{mcl} / \mathrm{pdf} / \mathrm{mcl}$-chap1.pdf;

13 http://edition.cnn.com/ELECTION/2004/pages/results/ballot.measures/.

142004 was an especially busy year for anti-gay marriage initiatives; see the discussion and analysis in Katie Lofton \& Donald P. Haider-Markel, The Politics of Same Sex Marriage Versus the Politics of Gay Civil Rights, in Rimmerman \& Wilcox (eds.) supra note 8.

15 Id. Amendment to the Ohio constitution requires (per Art XVI) the support of three fifths of each house of the legislature for a proposed amendment which is then put to the voters in a referendum. A bare majority of votes in favor is required to give legal effect to the proposal; https://www.legislature.ohio.gov/laws/ohio-constitution/section?const=16.01. 
Only a union between one man and one woman may be a marriage valid in or recognized by this state and its political subdivisions. This state and its political subdivisions shall not create or recognize a legal status for relationships of unmarried individuals that intends to approximate the design, qualities, significance or effect of marriage

The amendment lent further legal force to the sentiments enacted the previous year by the State legislature in a Defense of Marriage Act.

In all four States the issue continued to be contested in the political arena. But Windsor provided the trigger for the argument to move into the courts, prompting litigants to begin proceedings in the federal District Courts. ${ }^{16}$ While all of the Obergefell petitioners succeeded in their respective federal District courts, their cases were consolidated by the Sixth Circuit Court of Appeals in DeBoer v. Snyder, ${ }^{17}$ in which the court concluded that the States were not under any constitutional obligation to permit same sex marriage. The Eighth Circuit issued a similar judgment in Citizens for Equal Protection v. Bruning. ${ }^{18}$ In so doing, the Sixth and Eighth Circuits reached a quite different conclusion from that arrived at in other circuits.

One might have thought that the most doctrinally defensible way to invalidate the various State laws would have been to hold that: (a) the laws classified people according to their sexual orientation; (b) the classification had a discriminatory effect as it deprived gay people - and their children - of the various legal and financial (and perhaps cultural/moral/reputational) benefits enjoyed by married (as opposed to cohabiting) couples $;{ }^{19}$ (c) that sexual orientation discrimination was a suspect category for equal protection purposes and thus subject to strict or heightened scrutiny; (d) there was no compelling public policy reason to justify such discrimination. On this rationale, marriage per se would be a secondary or derivative issue: the true question would be the acceptable bounds of State sponsored sexual orientation discrimination. Insofar as such a technique would demand judicial innovation, that innovation would be limited to making explicit what was obviously implicit in Windsor and arguably implicit in the earlier sexual orientation discrimination judgments in Romer v. Evans ${ }^{20}$ and Lawrence v. Texas. ${ }^{21}$

This was the approach taken by the Court of Appeals Seventh Circuit in Baskin v. Bogan $^{22}$ in September 2014 when it invalidated the opposite-gender-only marriage laws of Indiana and Wisconsin, albeit that the Court also concluded that the laws could not even pass rational basis scrutiny. The same method was followed

16 For a helpful summary of the multiplicity of suits see David B. Cruz, Baker v. Nelson: Flotsam in the Tidal Wave of Windsor's Wake, 3 Ind. J. L. \& Soc. EQuality 184 (2015).

17 DeBoer v. Snyder, 772 F.3d 388 (6th Cir. 2014).

18 Citizens for Equal Prot. v. Bruning, 455 F. 3d 859, (8th Cir. 2006).

19 On the variegated reasons why same-sex couples in the U.S.A. might wish to marry see especially Goldberg, Why Marriage?, in Marriage at the Crossroads: LaW, Policy and the Brave New World of Twenty First Century Families (Marsha Garrison \& Elizabeth S. Scott, eds., 2012).

20 Romer v. Evans, 517 U.S. 620 (1996).

$21 \quad$ Lawrence v. Texas, 539 U.S. 558 (2003).

22 Baskin v. Bogan, 766 F. 3d 648 (7th Cir. 2014). The sole judgment is authored by Posner, J., It is lucidly and trenchantly dismissive of the States' various attempts to justify their laws: "[S]o full of holes that it cannot be taken seriously" (at 656); "[T]he grounds advanced by Indiana and Wisconsin are not only conjectural; they are totally implausible"; (at 671). 
by the majority of the Court of Appeals for the Ninth Circuit in Latta v. Otter, ${ }^{23}$ a judgment which rested on the court's own judgment earlier in 2014 in SmithKline Beecham Copt v. Abbott Labs ${ }^{24}$ that Windsor demanded that sexual orientation be treated as a suspect category.

In contrast, the Court of Appeal for the Fourth Circuit in Bostic v. Scahefer ${ }^{25}$ invalidated Virginia's constitutional provision that "only a union between one man and one woman may be a marriage valid in.... this Commonwealth" on the basis that marriage between two consenting adults was a liberty interest under the Fourteenth which could only be abridged by State law satisfying the strict scrutiny test and that Virginia's law did not pass the test. A similar approach was taken by Tenth Circuit Court of Appeals in Kitchen v. Herbert ${ }^{26}$ in relation to Utah and Oklahoma laws, albeit that the court also indicated that suspect category equal protection analysis would apply.

All of the circuit courts which invalidated the respective State laws had placed significant emphasis on Windsor as a guide to the meaning of the Fourteenth Amendment in respect of this issue. The weight of circuit court opinion and the fact that the Windsor majority remained in place pointed toward a Supreme Court reversal of the Sixth Circuit in Obergefell.

\section{The Majority Judgment}

As in Windsor, the majority judgment in Obergefell was authored by Kennedy, and joined - without any separate concurring opinions - by Ginsburg, Breyer, Sotomayer and Kagan. The judgment invalidated the laws of all four of the respondent States. While the majority certainly gave some weight to an equal protection analysis of the issue, the judgment seems to be rooted primarily in the conclusion that the right to marry is a liberty issue which entitles any and all adults to marry whichever other adult he/she might wish, subject only to State regulation which could pass muster under strict scrutiny review. ${ }^{27}$

\section{A. A LiBERTY ISSUE......}

Part II of the judgment ${ }^{28}$ dwells briefly on the centrality of marriage as a social institution in all known societies. Justice Kennedy is keen to portray marriage as an

\footnotetext{
Latta v. Otter, 771 F. 3d 456 (9th Cir. 2014).

24 SmithKline Beecham Corp. v. Abbott Labs., 740 F. 3d 471 (9th Cir. 2014). Abbot was an ant-trust case involving medicines used in HIV treatment in which one party, Abott, exercised a peremptory right to exclude a juror for no discernible reason other than that he was gay.

25 Bostic v. Schaefer, 760 F.3d 352 (4th Cir. 2014).

26 Kitchen v. Herbert, 755 F. 3d 1193 (10th Cir. 2014).

27 Which presumably - at least at present - leaves it open to States to retain restrictions based on age, mental competence, consanguinity and polygamy.

28 Part I very briefly recounts the history of the litigation.
} 
evolving or dynamic social institution, in terms both of the reasons for entering it and its legal effects on the participants:

For example, marriage was once viewed as an arrangement by the couple's parents based on political, religious, and financial concerns; but by the time of the Nation's founding it was understood to be a voluntary contract between a man and a woman. See Nancy F. CotT, Public Vows: A History of Marriage and the Nation 9-17 (2000); Stephanie Coontz, Marriage, a History: How Love Conquered MARRIAGe 15-16 (2005). As the role and status of women changed, the institution further evolved. Under the centuries-old doctrine of coverture, a married man and woman were treated by the State as a single, male-dominated legal entity. See 1 W. Blackstone, Commentaries on the Laws of England 430 (1765). As women gained legal, political, and property rights, and as society began to understand that women have their own equal dignity, the law of coverture was abandoned.... These and other developments in the institution of marriage over the past centuries were not mere superficial changes. Rather, they worked deep transformations in its structure, affecting aspects of marriage long viewed by many as essential....... ${ }^{29}$

The stress on the evolving nature of marriage was presumably laid in anticipation of the argument that the 'liberties' embraced by the Fourteenth Amendment comprised only those issues that could be said to have a clear and longstanding empirical root in the fabric of American life, and since same-sex marriage dated only back to 2003 - and then only in Massachusetts - it could not have that character. The thrust of Justice Kennedy's analysis seems to be to assert that the gender identity of spouses is an 'aspect' - and a 'deep' aspect - of the traditional understanding of marriage, but not an indispensable element of it. This proposition might have been argued more fully and more deeply grounded in empirical study. For example, the sub-title of the Coontz book referred to is 'How Love Conquered Marriage'. The book is a sweeping, cross-cultural historical survey of marriage. Kennedy's reference to it is rather skimpy, and might more helpfully have focused on chapter 1517, which trace developments in the United States in the post-1945 era, and make a credible case for the proposition that a - if not the - dominant motive for marriage in the near modern era lies in a reciprocal desire for companionship and emotional intimacy rather than child-rearing. ${ }^{30}$

The next section of Part II runs with the notion of changing understandings of 'equal dignity' in relation to the traditionally subordinate status of women vis à vis men and applies it to recent attitudinal changes in modern American society to homosexuality:

29 Obergefell v. Hodges, 135 S. Ct. 2584, 2588 (2015) (Kennedy, J.) emphasis added. Similarly 'deep transformations' perhaps, not mentioned by Justice Kennedy, would be the substantial facilitation of divorce and radical alternations in legal presumptions as to the distribution of financial assets and custody of children when divorce occurs.

30 Stephanie Coontz, The Way We Really Are: Coming to Terms with America's ChangING FAMILIES (1997) is perhaps a similarly useful source on the empirically ill-founded notion of the composition of the 'traditional' American family. 
Until the mid-20th century, same-sex intimacy long had been condemned as immoral by the state itself in most Western nations, a belief often embodied in the criminal law. For this reason, among others, many persons did not deem homosexuals to have dignity in their own distinct identity.... Same-sex intimacy remained a crime in many States....

For much of the 20th century, moreover, homosexuality was treated as an illness.... Only in more recent years have psychiatrists and others recognized that sexual orientation is both a normal expression of human sexuality and immutable...... ${ }^{31}$

This dynamic is portrayed as manifesting itself in culture and politics and law:

In the late 20th century, following substantial cultural and political developments, same-sex couples began to lead more open and public lives and to establish families. This development was followed by a quite extensive discussion of the issue in both governmental and private sectors and by a shift in public attitudes toward greater tolerance. ${ }^{[32]} \mathrm{As}$ a result, questions about the rights of gays and lesbians soon reached the courts, where the issue could be discussed in the formal discourse of the law.

This Court first gave detailed consideration to the legal status of homosexuals in Bowers v. Hardwick, 478 U.S. 186 (1986). There it upheld the constitutionality of a Georgia law deemed to criminalize certain homosexual acts. Ten years later, in Romer v. Evans, 517 U.S. 620 (1996), the Court invalidated an amendment to Colorado's Constitution that sought to foreclose any branch or political subdivision of the State from protecting persons against discrimination based on sexual orientation. Then, in 2003, the Court overruled Bowers, holding that laws making same-sex intimacy a crime "demea[n] the lives of homosexual persons." Lawrence v. Texas, 539 U.S. 558, 575.

Part III seeks to identify 'dignity and autonomy' as values synonymous with liberty under the Fourteenth. Justice Kennedy's opinion speeds through bits of the celebrated 1960s contraception cases ${ }^{33}$ which in part underpinned the majority judgment in Roe v. Wade. ${ }^{34}$ Kennedy does not invoke Roe here however. This implicit recasting of the organizing principle in the contraception cases as one

$31 \quad$ Obergefell v. Hodges, 135 S. Ct. 2584, 2596 (2015).

32 Kennedy, J. did not invoke any social science evidence on the point. Helpful sources are Paul R. Brewer, The Shifting Foundations of Public Opinion About Gay Rights, 65 J. Pol. 1208 (2003); Paul R. Brewer, Values, Political Knowledge and Public Opinion About Gay Rights, 67 PuB. Opinion. Q. 173 (2003).

33 Poe v. Ullman, 367 U.S. 497 (1961); Griswold v. Connecticut, 381 U.S. 479 (1965); Eisenstadt v. Baird, 405 U.S. 438 (1972).

34 Roe v. Wade, 410 U.S. 113 (1973). Mention of Roe was presumably eschewed out of a concern that it would further fan the flames of political controversy that the same-sex marriage question was already generating. 
concerned with 'dignity and autonomy' rather than 'privacy' involves something of a linguistic sleight of hand. There are six opinions in Griswold. The term 'dignity' appears once - in Justice Douglas's majority opinion. It appears once in Poe - in Justice Harlan's dissent. In the latest of the three cases, Eisenstadt, it is not used at all.

Justice Kennedy then carries this couplet of dignity and autonomy into a trio of 'marriage cases' in which State prohibitions on marriage were struck down. The first, chronological and in the judgment, is the Warren Court's well known (unanimous) opinion in Loving $v$. Virginia: ${ }^{35}$ the second and third are the more obscure decisions in Zablocki v. Redhail ${ }^{36}$ and Turner v. Saffley. ${ }^{37}$ In Loving, the Warren Court invalidated Virginia's racial discriminatory marriage laws, which forbade marriage between a white and non-white person; Zablocki held that Wisconsin's law which prevented fathers who defaulted on child support payments from marrying was unconstitutional ; while Turner took the same approach towards a Missouri law which precluded any prison inmate from marrying unless the prison governor considered there were compelling reasons to allow the inmate to do so.

It is difficult to avoid the conclusion that the majority in Obergefell is playing rather fast and loose with the respective ratios of the three 'marriage case' judgments in invoking all of them as a support for the notion that the 'fundamental' characteristic of marriage is indifferent to the gender(s) of the participants. Thus, for example, Justice Kennedy asserts "Loving did not ask about a right to inter-racial marriage". ${ }^{38}$ Unhappily, perhaps, this contention is manifestly incorrect. Most of the judgment in Loving is directed towards equal protection issues. But in respect of the liberty element of the Fourteenth Amendment the Court unequivocally couched its analysis in the language of a right to inter-racial marriage:

.....The freedom to marry has long been recognized as one of the vital personal rights essential to the orderly pursuit of happiness by free men....

To deny this fundamental freedom on so unsupportable a basis as the racial classifications embodied in these statutes, classifications so directly subversive of the principle of equality at the heart of the Fourteenth Amendment, is surely to deprive all the State's citizens of liberty without due process of law. The Fourteenth Amendment requires that the freedom of choice to marry not be restricted by invidious racial discriminations. Under our Constitution, the freedom to marry, or not marry, a person of another race resides with the individual, and cannot be infringed by the State.

Similarly, Justice Kennedy asserts that: "Turner did not ask about a 'right of inmates to marry'." ${ }^{39}$ But - very clearly - Turner did just that:

The right to marry, like many other rights, is subject to substantial restrictions as a result of incarceration. Many important attributes of

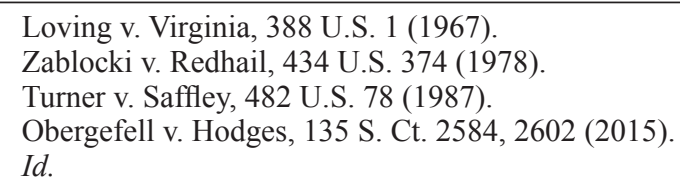


marriage remain, however, after taking into account the limitations imposed by prison life. First, inmate marriages, like others, are expressions of emotional support and public commitment. These elements ... are an important and significant aspect of the marital relationship. In addition, many religions recognize marriage as having spiritual significance; for some inmates and their spouses, therefore, the commitment of marriage may be an exercise of religious faith as well as an expression of personal dedication. Third, most inmates eventually will be released by parole or commutation, and therefore most inmate marriages are formed in the expectation that they ultimately will be fully consummated. Finally, marital status often is a precondition to the receipt of government benefits (e.g., Social Security benefits), property rights (e.g., tenancy by the entirety, inheritance rights), and other, less tangible benefits (e.g., legitimation of children born out of wedlock). These incidents of marriage, like the religious and personal aspects of the marriage commitment, are unaffected by the fact of confinement or the pursuit of legitimate corrections goals. ${ }^{40}$

As to Zablocki, this case: "did not ask about a right of fathers with unpaid child support duties to marry" ${ }^{41}$ Once again, the assertion is hard to defend, giving that the clinching factor in the majority judgment appeared to be the concern that some 'deadbeat dads' would never be able to marry as their poverty would permanently preclude them from meeting their child support obligations:

....Some of those in the affected class, like appellee, will never be able to obtain the necessary court order, because they either lack the financial means to meet their support obligations or cannot prove that their children will not become public charges. These persons are absolutely prevented from getting married. Many others, able in theory to satisfy the statute's requirements, will be sufficiently burdened by having to do so that they will, in effect be coerced into forgoing their right to marry. ${ }^{42}$

All three cases were of course decided in eras when - on the majority's own argument - being homosexual was to be part of a stigmatized and marginalized minority. It is easy to suggest that they therefore offer no support for the substance of Kennedy, J.'s conclusion. But that suggestion misses - or perhaps deliberately ignores the crucial point. The 'marriage cases' are perhaps less concerned with the right to marry per se as with the States' limited capacity to deprive a person of aspects of her/his individuality; that he she is not deserving of the full panoply of individual rights because (per Loving) she/he is black or (per Turner) she/he is a prisoner or (per Zablocki) he/she is an indigent parent. A denial of a fundamental right is a particularistic manifestation of a broader liberty value; to be recognized by law as an individual.

Thus we might conclude that discriminatory anti-gay laws (as to employment, or private sexual conduct, or public displays of affection) laws rested on the legislative premise that their targets were not 'individuals' in the full sense, but a lesser

40 Turner v. Safley, 482 U.S. 78, 95-96 (1987) (internal citations omitted) (emphasis added).

41 Obergefell v. Hodges, 135 S. Ct. 2584, 2598 (2015).

42 Zablocki v. Redhail, 434 U.S. 374, 87 (1978). 
breed of person properly excludable from some of the manifestations of liberty enjoyed by 'normal' people. This is a point developed further below in relation to part of the dissenting judgment offered by Chief Justice Roberts.

It is very noticeable in Obergefell that while the majority makes copious references to previous Court decisions, it rarely quotes from any of them at any length. A short passage from Griswold is invoked (perhaps to underline the point that even fifty years ago marriage was recognized as having a value beyond child-rearing):

\begin{abstract}
Marriage is a coming together for better or for worse, hopefully enduring, and intimate to the degree of being sacred. It is an association that promotes a way of life, not causes; a harmony in living, not political faiths; a bilateral loyalty, not commercial or social projects. Yet it is an association for as noble a purpose as any involved in our prior decisions. ${ }^{43}$
\end{abstract}

As a technique, this is quite curious. One might initially suppose this is because - as alluded to above - any extensive quotation would undermine the majority's liberty argument. But that is certainly not the case. Consider, for example, the following passage in Zablocki, which roots the right to marry within the broader right of an individual's entitlement to privacy, ${ }^{44}$ a concept which is readily understandable as gender-indifferent:

Cases subsequent to Griswold and Loving have routinely categorized the decision to marry as among the personal decisions protected by the right of privacy. See generally Whalen v. Roe, 429 U. S. 598-600, and fn. 23-26 (1977). For example, last Term, in Carey v. Population Services International, 431 U. S. 678 (1977), we declared:

"While the outer limits of [the right of personal privacy] have not been marked by the Court, it is clear that among the decisions that an individual may make without unjustified government interference are personal decisions 'relating to marriage, Loving v. Virginia, 388 U. S. 1, 388 U. S. 12 (1967); procreation, Skinner v. Oklahoma ex rel. Williamson, $316 \mathrm{U}$. S. 535, 541-542 (1942); contraception, Eisenstadt v. Baird, 405 U.S. at 405 U. S. 453-454; id. at 405 U. S. 460, 463-465 (WHITE, J., concurring in result); family relationships, Prince v. Massachusetts, 321 U. S. 158, 321 U. S. 166 (1944); and child rearing and education, Pierce v. Society of Sisters, 268 U. S. 510, 535 (1925); Meyer v. Nebraska, [262 U.S. 390, 262 U. S. 399 (1923)]."

Id. at 431 U. S. 684-685, quoting Roe v. Wade, 410 U. S. 113, 410 U. S. 152-153 (1973). See also Cleveland Board of Education v. LaFleur, 414 U. S. 632, 414 U. S. 639-640 (1974) ("This Court has long recognized

43 Obergefell v. Hodges, 135 S. Ct. 2584, 2599-600 (2015).Obviously, given that Griswold concerned the entitlement of a married couple to access the contraceptives that would allow them to have non-procreative sex with each other.

44 In the classic Warren and Brandeis sense as a right to be let alone, not a right to keep things hidden; Samuel D. Warren \& Louis D. Brandeis, The Right to Privacy, 4 Harv. L. Rev. 193 (1899). 
that freedom of personal choice in matters of marriage and family life is one of the liberties protected by the Due Process Clause of the Fourteenth Amendment"); Smith v. Organization of Foster Families, 431 U. S. 816, 431 U. S. 842-844 (1977); Moore v. East Cleveland, 431 U. S. 494, 431 U. S. 499 (1977); Paul v. Davis, 424 U. S. 693, 424 U. S. 713 (1976). ${ }^{45}$

The final paragraph of this passage might be the most helpful to the majority's argument :

It is not surprising that the decision to marry has been placed on the same level of importance as decisions relating to procreation, childbirth, childrearing, and family relationships. As the facts of this case illustrate, it would make little sense to recognize a right of privacy with respect to other matters of family life and not with respect to the decision to enter the relationship that is the foundation of the family in our society. ${ }^{46}$

There is an obvious danger that the copious citation of authority without any extensive, textually rooted consideration of that authority would expose the majority's conclusion to the charge that it is essentially creating rather than discovering particular 'liberties', and as such is overstepping the limits of its proper constitutional role. We return to this point below. It is therefore perhaps unfortunate that Justice Kennedy felt the need to engage with liberty issues at all, given that his judgment could have rested on what seems to have been regarded by the majority as a secondary ground - that of equal protection.

\section{B. ....And/Or AN EQUAL PRotection ISSUE}

In Windsor, the majority had held that the Fifth Amendment contained an implied equal protection proviso and - more broadly - that the two concepts would often be so entangled that a breach on one basis would necessarily entail breach of the other. Justice Kennedy seems to have followed a similar path in Obergefell, observing that there is a 'synergy' between the two concepts. The crucial passage on the equal protection point is however rather cursory:

[T] he marriage laws enforced by the respondents are in essence unequal: same-sex couples are denied all the benefits afforded to opposite-sex couples and are barred from exercising a fundamental right. Especially against a long history of disapproval of their relationships, this denial to same-sex couples of the right to marry works a grave and continuing harm. The imposition of this disability on gays and lesbians serves to disrespect and subordinate them.... ${ }^{47}$

It might have been helpful if at this juncture the majority has spelled in considerably more detail just what the 'benefits' is issue were, and in what respects same-sex partners were disrespected and subordinated. Justice Kennedy touched briefly

\footnotetext{
Zablocki v. Redhail, 434 U.S. 374, 384-385 (1978).

$I d$. at 385 ((emphasis added).

Obergefell v. Hodges, 135 S. Ct. 2584, 2604 (2015).
} 
on these points in Part I of the judgment, but they were not drawn out at any length. The only issue raised in relation to Mr. Obergefell - whose partner had died - was that he could not register as the surviving spouse on his partner's death certificate. That is not the weightiest of issues. The point noted under Michigan law was arguably much more substantial; gay couples could adopt children only as individuals, not as (unlike a married man/woman) a couple. Thus if the adopter partner died, the surviving partner would have no legal custodial rights vis à vis the deceased partner's adoptive children. No 'tangible' equal protection issues were highlighted raise at all in respect of Tennessee and Kentucky. Nor did Justice Kennedy make anything significant of the deleterious effects on same sex couples of the 'disapproval' to which he referred. Similarly, the majority made nothing of the point that the State laws also forbade the creation or recognition of any form of civil partnership that would grant same sex couples the tangible benefits bestowed on married couples. For the lawmaking majorities in those States 'separate and unequal' was evidently the proper moral position.

The balance of the majority judgment is certainly shaped to some extent by the way that the various cases joined in Obergefell were pleaded and argued in the lower federal courts. Those pleadings and arguments do appear to owe rather more to a liberty than to an equal protection analysis of the issue, but it is unfortunate that the majority did not rest its judgment (much) more firmly on an equal protection basis. Had it done so, it might have reduced the significance of the most problematic part of its decision.

\section{ON the Separation of Powers}

Perhaps the most peculiar self-inflicted wound that the majority deals to the legitimacy of its conclusion is this sentence in Part IV of the judgment: ${ }^{48}$

Of course, the Constitution contemplates that democracy is the appropriate process for change, so long as that process does not abridge fundamental rights.

The notion that 'fundamental rights'49 and 'democracy' can ever be values that are at odds with each other is extraordinary in the American context, and invites the obvious accusation that the Court is acting in an 'undemocratic' fashion. A better form of words to set the scene in Part IV of the judgment would surely have been:

Of course, the understanding of democracy enshrined in our Constitution contemplates that majoritarian lawmaking through State or Congressional measures is the appropriate process for change, so long as those measures do not abridge fundamental rights. Our democracy has always envisaged that the courts will protect fundamental rights against legislative interference.

\footnotetext{
48 Obergefell v. Hodges, 153 S. Ct. 2584, 2605 (2015).

49 One might assume that the majority includes the notion of equal protection as an element of 'fundamental rights'.
} 
The unhappy nature of the majority's phraseology becomes clearer when Kennedy goes on just a few lines later to invoke the classic modern judicial formulation of the way in which the constitution reconciles understandings of 'democracy' and fundamental rights -Justice Jackson's speech in West Virginia Board of Education v. Barnette. ${ }^{50}$ This is perhaps where the majority should have more starkly staked out and clearly articulated its ground: that there is more to the notion of 'democracy' than legal deference to electoral politics.

The argument is admittedly difficult to carry on the same sex marriage issue simply because so many States wished to forbid it. A recurrent and contentious element of the Court's death penalty jurisprudence in the modern era has been the use of State head counting as an aide to assessing the continued constitutionality of death penalty legislation. The technique was first deployed shortly after Furman v. Georgia ${ }^{51}$ in Coker v. Georgia, ${ }^{52}$ when the Court felt able to conclude that imposing the death penalty for the rape of an adult woman was cruel and unusual punishment because only one State did it. Subsequent use of the counting method in death penalty cases has been far more contentious. ${ }^{53}$

This is in part because it can be portrayed as a back door route to constitutional amendment. A rule of constitutional law resting (wholly or in substantial part) on a head count which comprises fewer than the three quarters of States whose assent is required for constitutional amendment has dubious legitimacy in quantitative substantive terms. Procedural concerns also blend in with matters of substance. Voting behavior (whether of electors or legislators) in States may be significantly affected by the normative nature of 'the law' being voted upon. Individuals may be more willing to support (or be less likely to oppose) a new law intended to affect only a particular State, and which could quite easily be changed within the State in future than, a law intended to amend the Constitution. ${ }^{54}$

Relatedly, the practice is obviously problematic insofar as it can be portrayed as shutting down political debate. If the court has declared a particular sentencing policy unconstitutional, then the pro-policy minority cannot increase to a majority; indeed it disappears altogether. Movement from the status quo would require the court to change its collective mind or - a most unlikely proposition - that the requisite majorities suddenly and then sustainably appear in both Congress and the States for the constitutional amendment expressly permitting the policy to be applied.

There is no express mention of head counting jurisprudence in Kennedy's opinion. The technique could presumably have no legitimacy as a source of constitutional law if only a dozen States recognize same-sex marriage, while nearly forty prohibit it. And it is perhaps around this question of numbers that the majority judgment faces its greatest difficulty.

\footnotetext{
$50 \quad$ W. Virginia. State Bd. of Educ. v. Barnette, 319 U.S. 624, 638 (1943).

Furman v. Georgia, 408 U.S. 238 (1972).

Coker v. Georgia, 433 U.S. 584 (1977).

53 See for example Ford v. Wainwright, 477 U.S. 399 (1983); Atkins v. Virginia, 536 U.S. 304 (2002).

54 Either because the voter recognizes that the law may turn out to have less desirable effects than she hopes, or that her own views might evolve, in which events she might wish the law to be changed; or that she does not think it proper for voters in States which do not share her view to be obliged to do so.
} 
Even before Windsor, same-sex marriage as a purely 'political' as opposed to 'constitutional' issue ${ }^{55}$ was being vigorously argued in most of the States. Windsor lent those arguments sharper focus. But one could hardly suggest the arguments - as political arguments -were resolved. There is no popular 'majority' favoring same sex marriage. The prohibitory laws of Ohio and Tennessee and Michigan and Kentucky cannot be denied constitutional validity on the basis that they are aberrant departures from a widely accepted norm. The crux of the majority view must be that the norm itself is an aberrant departure from the understanding of democracy that the constitution exists to protect.

That premise is diluted, or perhaps obscured, by an odd passage at the start of part IV of Kennedy's judgment which seems to say that because there has been a great deal of political argument on the question, in all sorts of ways and all sorts of forums, an 'enhanced understanding of the issue ${ }^{56}$ has emerged; which understanding legitimizes the court's intervention - on the side of those possessed of this 'enhanced understanding'. This passage lends itself to the interpretation that the majority is simply turning (a primitive conception of) democracy upside down, and allowing a minority political viewpoint to trump a majoritarian one.

That perception may be reinforced by the very cursory attention the majority gave to the (purported) policy arguments offered by the States to support their respective laws. Justice Kennedy simply dismisses as 'counterintuitive' the assertion that same sex marriage would harm marriage as an institution because it would deter opposite gender couples from marrying. A more fully reasoned rebuttal of that argument and other supportive propositions might have lent greater weight to the majority judgment.

All in all, it is difficult to avoid the conclusion that the majority judgment is less than convincing, and that giving prominence given to the liberty rather than equal protection dimension of the issue was a poor strategic choice. Happily however for the majority of the Court, the reasoning offered up by the dissent has even less to commend it.

\section{The Dissenting Judgments}

Working perhaps on a the basis that multiple individual dissents carry more weight than a single opinion, Chief Justice Roberts and Justices Scalia, Thomas and Alito all offered their own judgments. The Chief Justice produced a (for the most part) carefully reasoned and expressed dissent, which identified some obvious shortcomings in the majority's opinion, albeit without acknowledging the weaknesses in its own position. The three other dissents, in contrast, are notable primarily for their heady mix of petulance and irrelevance, and could be thought to serve primarily to undermine such cogency as the opinion of the Chief Justice might possess.

55 Any attempt to sustain a stark dichotomy between 'political' and 'constitutional' issues is fraught with difficulty. It would be silly to assume that some people's views as to what they consider politically desirable is not shaped (and perhaps profoundly) by what they regard as constitutionally permissible.

56 Obergefell v. Hodges, 135 S. Ct. 2584, 2591 (2015). 


\title{
A. Chief Justice Roberts
}

\begin{abstract}
Understand well what this dissent is about: It is not about whether, in my judgment, the institution of marriage should be changed to include same-sex couples. It is instead about whether, in our democratic republic, that decision should rest with the people acting through their elected representatives, or with five lawyers who happen to hold commissions authorizing them to resolve legal disputes according to law. The Constitution leaves no doubt about the answer..$^{57}$
\end{abstract}

The crux of the Chief Justice's critique of Kennedy's opinion is presented as lying not - crudely - in a question of substantive morality (i.e. who should be allowed to marry), but in a question of the separation of powers (i.e. which governmental institutions should be empowered to determine which aspects of that substantive moral issue). The analysis proceeds from the premise for several hundred years both Congress ${ }^{58}$ and the States have been controlled by lawmaking majorities which have only conceived of marriage as encompassing opposite gender partners; and that the matter to be resolved is how departures from or modifications of that traditional understanding should properly be achieved.

Simply put, any legal 'right' that individuals might have to marry a person of the same gender is a right that can be derived only from State law - whether from the State constitution or legislation or common law. As legal communities, operating within specific geographical boundaries, States may (subject only to narrowly defined Fourteenth Amendment restrictions) allow or prohibit such marriages as they each think fit. And it is open to individuals who dislike the substance of the legal choice made in their home State to move to State with laws more to their liking or to stay put and make efforts to have the unwanted law changed.

The Chief Justice's 'liberty' is a mechanism to safeguard long accepted values against newly emergent majoritarian threats. The accepted 'liberty' in issue in Meyer v. Nebraska was to teach one's children a foreign language: in Pierce it was to educate one's child in a private school. Such choices, even from the Meyer/ Pierce perspective of the 1920s, were properly seen to stretch back to and beyond the revolutionary era.

Because there is no such traditional basis in respect of marriage between same sex partners, majoritarian denial of such marriages cannot infringe a liberty interest. For the Chief Justice, that spouses be of opposite genders is not simply a deeply rooted element of marriage, but an irremovable core. On this reasoning, same sex marriage could eventually become sufficiently 'traditional' that it would amount to a liberty interest, but that state of affairs lies many years in the future.

Chief Justice Roberts obviously accepts that 'traditional understandings' can be altered by constitutional amendment. Nor does he suggest that Loving, or $\mathrm{Za}$ blocki or Turner mis-stated the restrictive effect of the Fourteenth Amendment on State autonomy on the question of who might get married at all (and to whom). His

\section{Id. at 2612}

58 Accepting that defining the elements of marriage is essentially a State enterprise, it should be recalled that in the early years of the U.S.A.'s history Congress exercised 'State-like' powers over the territories and continues to do so in respect of Washington D.C. and inter alia, Puerto Rico, the U.S. Virgin Islands and American Samoa. 
position is rather that those cases were decided without any doubt being cast on the correctness of the assumption that marriage could only be a male/female relationship. As such, they provide no authority in the proper legal sense for the conclusion that 'liberty' embraces same-sex marriage.

$\mathrm{He}$ is similarly dismissive of the contraception and privacy cases as an authority for such a proposition: in part because (obviously) the State laws in issue there were directed at mixed sex couples; and in part because the laws purported to impose criminal penalties on the targeted individuals. Similarly, Lawrence is seen as irrelevant because - notwithstanding it forbids discriminates on the basis of sexual orientation - that protection is limited to a freedom from criminal sanctioning of an essentially private (intimate) act. Proponents of same sex marriage in contrast: “....do not seek privacy. Quite the opposite, they seek public recognition of their relationships, along with corresponding government benefits". 59

If there is no 'liberty' in issue, it is therefore open to the States to deny same sex partners the right to marry each other as long as such policy can be shown to have a rational basis: "And a State's decision to maintain the meaning of marriage that has persisted in every culture throughout human history can hardly be called irrational." ${ }^{60}$ In short, the gist of the Chief Justice's dissent is that the majority has improperly taken the court into the legislative arena, and thereby resolved an essentially political dispute through legal means.

To that point, the Chief Justice's argument has an obvious credibility. That credibility is eroded somewhat by the simplistic assertion - embraced to some extent as noted above by the majority as well - that the majority decision is necessarily 'anti-democratic'. But where the dissent most loses force is in Roberts' attempts to bolster his more abstract criticism with reference to historical precedent, by equating the majority decision in Obergefell with the 'majority' views in two of the Court's most controversial judgments: Dred Scott v. Sandford ${ }^{61}$ and Lochner v. New York. ${ }^{62}$

The reference back to Dred Scott is quite extraordinary. In part, this is because of simple error. Chief Justice Roberts asserts for example that 'the Court' in Dred Scott held that the Fifth Amendment protected a slaveowner's liberty to take his slaves into the territories and keep them there against Congressional legislation. That assertion is - as Roberts must surely know - just plain wrong. Chief Justice Taney offered up that idea (almost in passing) in his leading judgment, but only two other members of the court clearly concurred with that conclusion ${ }^{63}$. More broadly, Chief Justice Roberts' reference to Dred Scott is quite bizarre because what was accepted by the majority of the court was that (most) blacks could not be citizens of the United

$59 \quad$ Obergefell v. Hodges, 135 S. Ct. 2584, 2620 (2015). There is a temptation to see this as akin to an "as long as they don't frighten the horses" approach to gay rights. That may be Chief Justice Roberts personal view. However there is in fact some relatively substantial empirical evidence to suggest that a significant number of voters who favored the opposite gender marriage laws would also have been content to prohibit sexual orientation discrimination in other fields, especially employment; see Lofton supra note 14; Wilcox et al, If I Bend This Far I Will Break: Public Opinion About Same Sex Marriage, in Rimmerman \& Wilcox eds., supra note 8.

60 Obergefell v. Hodges, 135 S. Ct. 2584, 2611 (2015).

61 Dred Scott v. Sandford, 60 U.S. 393 (1856).

62 Lochner v. New York, 198 U.S. 45 (1905).

63 See Don Fehrenbacher, The Dred Scott Case: Its Significance in American Law and Politics, CH. 17 (1978). 
States because they had for many years (before, during and after the revolution) been regarded as inferior beings by whites. ${ }^{64}$ They were not - to return to a point flagged above - 'individuals'. We might perhaps pause to recall Taney's words:

It is difficult at this day to realize the state of public opinion in relation to that unfortunate race which prevailed in the civilized and enlightened portions of the world at the time of the Declaration of Independence and when the Constitution of the United States was framed and adopted. But the public history of every European nation displays it in a manner too plain to be mistaken.

They had for more than a century before been regarded as beings of an inferior order, and altogether unfit to associate with the white race either in social or political relations, and so far inferior that they had no rights which the white man was bound to respect, and that the negro might justly and lawfully be reduced to slavery for his benefit.....

.... [A] perpetual and impassable barrier was intended to be erected between the white race and the one which they had reduced to slavery. And no distinction in this respect was made between the free negro or mulatto and the slave, but this stigma of the deepest degradation was fixed upon the whole race. ${ }^{65}$

And then wonder if they could be applied - in a diluted sense of course - with some felicity to majoritarian sentiments towards gay Americans in the recent past. In denying legitimacy - and of course legality - to the continued stigmatization of a minority group by the majority, Justice Kennedy's judgment is in its most important respect entirely antithetic to 'the court's' decision in Dred Scott.

The Chief Justice's invocation of the 1905 judgment in Lochner perhaps does less - but still some - damage to the cogency of his argument. In Lochner, a 5-4 majority invalidated New York legislation which sought to place a ten hour per day maximum on working hours in, inter alia, bakeries. Roberts is manifestly correct in portraying the majority decision in Lochner as 'discredited'. However he misses - or perhaps chooses not to mention - the rather obvious difficulty in seeking to equate that majority decision with the majority view in Obergefell.

The analogy is patently flawed. The intention of the New York legislature in 1897 was to protect an economically weak minority of employees from exploitation by their economically much more powerful employers. The Lochner majority of course portrayed that law as one restricting the liberty of employees to work (if they 'chose') eleven, twelve or more hours per day. Whether through ignorance or mendacity, the Lochner majority closed its eyes to the political realities which the law addressed. The State initiatives in issue in Obergefell could hardly be portrayed

${ }_{64}$ See, e.g. Edward S. Corwin, The Dred Scott Decision in the Light of Contemporary Legal Doctrines, Am. Hist. Rev. 52 (1911); Edward S. Corwin, Due Process of Law Before the Civil War (parts 1 and 2), Harvard L. REv. 366 \& 460 (1910-11); Wallace Mendelson, Dred Scott's Case Reconsidered, Minn. L. Rev. 16 (1953); David S. Bogan, The Maryland Context of Dred Scott, Am. J. LeG. Hist. 381 (1990-91). 
as protecting a weak minority - their purpose is further to disadvantage that minority; and, in States where the relevant law takes the form of a constitutional amendment requiring a super-majority, to entrench that disadvantage beyond the ordinary political process. The majority decision in Lochner perpetuated oppressive conduct; the majority decision in Obergefell ends oppressive conduct. ${ }^{66}$

\section{B. JUSTICE SCALIA}

The Chief Justice's dissent is however a model of intellectual rigor and linguistic restraint when set alongside the splenetic tantrum offered up by Justice Scalia who introduces his judgment in apocalyptic terms:

Today's decree says that my Ruler, and the Ruler of 320 million Americans coast-to-coast, is a majority of the nine lawyers on the Supreme Court. The opinion in these cases is the furthest extension in fact-and the furthest extension one can even imagine - of the Court's claimed power to create "liberties" that the Constitution and its Amendments neglect to mention. This practice of constitutional revision by an unelected committee of nine, always accompanied (as it is today) by extravagant praise of liberty, robs the People of the most important liberty they asserted in the Declaration of Independence and won in the Revolution of 1776: the freedom to govern themselves. ${ }^{67}$

Scalia of course muddles the notion of 'the People' with the country's various geographically discrete lawmaking majorities which act through legislation or constitutional amendment under State constitutions. These are not 'the People'. They are 'mini-Peoples - (often) teeny tiny minorities of 'the People'. It remains entirely open to 'the People' to decide that the Court has lent the national constitution an unacceptable meaning, and to alter the constitution accordingly: "No State nor the Congress nor the President nor any federal court nor any federal executive body shall ever permit nor recognize as a marriage any legal relationship between two persons if those persons are of the same gender" might be a form of words that does the trick. And so long as the mini-Peoples of the three quarters of the States can simultaneously coalesce in support of such sentiments, then the 'political' process will have settled the issue until such time as sufficient mini-Peoples coalesce in favor of a new settlement.

Justice Scalia's hysteria is repeated in a passage in which he accuses the majority of being:

...willing to say that any citizen who does not agree with that, who adheres to what was, until 15 years ago, the unanimous judgment of all generations and all societies, stands against the Constitution. ${ }^{68}$

${ }_{66}$ Chief Justice Roberts also neglects to mention that a (perhaps the) primary reason for the rejection of Lochner by the new deal court was its acceptance in products that economic policies of general application were most unlikely to raise fundamental rights issues. The obvious point of reference is the famous footnote 4 of United States v. Carolene Prod. Co., 304 U.S. 144, 154 (1938).

67 Obergefell v. Hodges, 135 S. Ct. 2584, 2627 (2015).

68 Obergefell v. Hodges, 135 S. Ct. 2584, 2630 (2015). 
This is just the silliest of things to say. It is - and one might note it has always been - a tenet of the constitutional settlement that any person or groups of people are ever at 'liberty' to seek to have the constitution amended; so long as that is done in an orderly, peaceful (and one hesitates to say it 'democratic') fashion. On this reasoning - one wonders how Chief Justice Roberts would treat the point anyone who suggested Dred Scott or Lochner was wrongly decided 'stood against the Constitution'. The premise is nonsensical. Justice Scalia may have been a judge of formidable intellect and learning. Opinions such as the one he produced in Obergefell do little to buttress any such conclusion. The similar sentiments of Justices Thomas and Alito do not merit separate attention.

\section{CONCLUSION}

Chief Justice Roberts, alone among the dissenters, also suggests that he might have formed part of the majority had its conclusion rested on the narrowly formulated (and adequately evidenced) basis that the impugned State laws violated the Equal Protection clause because they denied a range of fiscal or legal benefits to gay couples. It is perhaps unfortunate that the case was not argued and resolved on that basis. A 6-3 majority, carrying George W. Bush's nominee as Chief Justice, would have lent the judgment greater legitimacy than the 5-4 balance we have been given.

The Supreme Court's (unanimous) decisions ${ }^{69}$ in Brown v. Board of Education were of course met with ferocious resistance in many southern States and with deliberate obstructionism in many other parts of the country. ${ }^{70}$ Thus far, there is little indication that the 'defeated' States on the marriage issue will offer either formally or informally any such obstructionism. In that practical sense, the legitimacy of the majority judgment is not seriously in question.

In the immediate aftermath of Obergefell, some headlines were made by a woman named Kim Davis, a county registrar in Kentucky:

MOREHEAD, Ky. - Defying the Supreme Court and saying she was acting "under God's authority," a county clerk in Kentucky denied marriage licenses to gay couples on Tuesday, less than a day after the court rejected her request for a dely.

A raucous scene unfolded shortly after 8 a.m. at the Rowan County Courthouse here as two same-sex couples walked into the county clerk's

69 There are two. The initial judgment of Brown v. Bd. of Educ., 347 U.S. 483 (1954) held racial segregation in State schools per se breached the Equal Protection clause. The second judgment a year later began the process of planning to give practical effect to the first; Brown v. Bd. of Educ. of Topeka, Kan., 349 U.S. 294 (1955).

$70 \quad$ See e.g. Alexander M. Bickel, The Decade of School Desegregation: Progress and Prospects, 64 Colum. L. Rev. 193 (1964); John Kaplan, Comment: The Decade of School Desegregation: Progress and Prospects, 64 Colum. L. Rev. 223 (1964). For a much more immediate and graphic survey of southern responses see Another Tragic Era? U.S. News \& World ReP. (Oct. 4, 1957) at 51.. 
office, followed by a throng of journalists and chanting protesters on both sides of the issue. One couple, David Ermold and David Moore, tried to engage the county clerk, Kim Davis, in a debate before the cameras, but as she had before, she turned them away, saying repeatedly that she would not issue licenses to any couples, gay or straight.

"Under whose authority?" Mr. Ermold asked.

"Under God's authority," Ms. Davis replied. ${ }^{71}$

Davis' defiance was in notable contrast to the welcome afforded to the judgment by the current incumbents of senior State executive office in Kentucky, all of whom uniformly pledged to facilitate its effective implementation. ${ }^{72}$ Davis was subsequently jailed by a federal court for five days for contempt of court in refusing to issue marriage licenses. ${ }^{73}$ A rally celebrating her release was attended by two Republican presidential candidates, Senator Ted Cruz of Florida and former Arkansas Governor, Mike Huckabee.

The issue did not retain much political traction as an issue of contention in the 2016 presidential election, as both Clinton and Trump offered support for the notion of same sex marriage. That has little bearing however on the more empirically significant question of whether some State officials, especially at the lower level, adopt policies and practices intended to obstruct implementation of the law, particularly on the basis that government officials who are opposed on religious grounds to gay marriage should not be compelled to issue marriage licenses to gay couples. ${ }^{74}$ As yet, there is little indication that gay couples have met serious obstacles. ${ }^{75}$

It is therefore tempting to conclude that we may well find that in ten years time the notion that a man might marry a man and a woman a woman will have become so normalized in so many parts of the United States that the class of 2027 will look back at Obergefell and wonder what all the fuss was about. It will no doubt be a case taught in law schools and discussed in law journals as a vehicle to explore the contesting principles of judicial 'activism' and 'restraint'. As such the judgment(s) will remain important elements of constitutional jurisprudence. But it should perhaps be hoped that those questions of doctrinal theory do not obscure

$71 \quad$ Alan Blinder \& Richard Perez-Pena, Kentucky Clerk Denies Same-Sex Marriage Licenses, Defying Court, N.Y. Times, (Sept. 1, 2015); http://www.nytimes.com/2015/09/02/us/ same-sex-marriage-kentucky-kim-davis.html?_r=0.

72 See e.e.g. WKYT News, Kentucky leaders react to gay marriage ruling, WKYT NEws, (June 26, 2015); http://www.wkyt.com/home/headlines/Kentucky-leaders-react-to-gaymarriage-ruling-310082291.html

73 Alan Blinder \& Richard Perez-Pena, Kim Davis, Released From Kentucky Jail, Won't Say If She Will Keep Defying Court, N.Y. Times (Sept. 8, 2015); http://www.nytimes. com/2015/09/09/us/kim-davis-same-sex-marriage.html.

74 One can certainly anticipate lawsuits brought by such official against their employers on First Amendment grounds should they be dismissed or otherwise sanctioned for refusing to do so.

75 See for example Erik Eckholm \& Manny Fernandez, After Same-Sex Marriage Ruling, Southern States Fall in Line, N.Y. Times (June 29, 2015) https://www.nytimes. com/2015/06/30/us/after-same-sex-marriage-ruling-southern-states-fall-in-line. html?mcubz=0. 
the profoundly important impact of the judgment in freeing a long stigmatized and discriminated against minority of 'the people' from the second class legal and cultural status they had been explicitly assigned by their respective States' intolerant legislative majorities. Judge Posner puts the point perfectly in Baskin v. Bogan:

Wisconsin's remaining argument is that the ban on same-sex marriage is the outcome of a democratic process - the enactment of a constitutional ban by popular vote. But homosexuals are only a small part of the state's population-2.8 percent, we said, grouping transgendered and bisexual persons with homosexuals. Minorities trampled on by the democratic process have recourse to the courts; the recourse is called constitutional law. ${ }^{76}$

76 Baskin v. Bogan, 766 F. 3d 648, 671 (7th Cir. 2014). 